\title{
Modelling Market Pressure and Intervention Index for Pakistan Using Cointegration Approach
}

\author{
Gilal, Muhammad Akram ${ }^{1} \&$ Chandio, Rafiq Ahmad ${ }^{1}$ \\ ${ }^{1}$ Department of Economics, University of Sindh Jamshoro, Pakistan \\ Correspondence: Gilal, Muhammad Akram, Department of Economics, University of Sindh Jamshoro, Pakistan. \\ Tel: 92-22-921-3235. E-mail: akram.gilal@usindh.edu.pk
}

Received: December 19, 2013

Accepted: January 9, 2014

Online Published: March 25, 2014

doi:10.5539/ijef.v6n4p51

URL: http://dx.doi.org/10.5539/ijef.v6n4p51

\begin{abstract}
To work with a model based approach to Exchange Market Pressure, estimation on level data may be spurious. This paper addresses that issue by utilizing a Cointegration framework to estimate parameters of a Weymark's (1995) model. Based on Weymark (1995) model's estimated parameters, an exchange market pressure and an intervention index is constructed. The results indicate downward pressure and active Central Bank intervention. Post reform period shows a drop in market pressure and the central bank foreign exchange intervention. An intervention index mean value for the entire period suggests that foreign exchange reserves relieved most of the pressure. This has an important policy implication that monetary authorities in Pakistan are not independent in formulating an effective monetary policy.
\end{abstract}

Keywords: financial markets, term structure of interest rate, central bank intervention

\section{Introduction}

Exchange Market Pressure refers to money market disequilibrium that arises due to non-zero excess demand for domestic currency in foreign exchange market. Nominal exchange rate changes reflect the extent of market pressure in the absence of Central Bank intervention. It is argued that nominal exchange rate changes have consequences for domestic macroeconomic variables which include domestic output growth, increase in domestic prices, balance of trade, firm's price-setting behaviour in high inflation countries, foreign debt burden of the country, balance of payments and the stability of domestic financial system. It has been observed that Central Banks generally intervene in foreign exchange market to avoid undesirable consequences of exchange rate changes. In such circumstances, instead of exchange rate changes alone, sum of exchange rate and foreign exchange reserve changes fully describe the extent of foreign exchange market disequilibrium.

Girton and Roper (1977) first derived exchange market pressure index using monetary approach to balance of payments. It is a simple sum of exchange rate and foreign exchange reserves changes. Since both exchange rate and foreign exchange reserve changes are equally weighted; therefore the construction of Exchange Market Pressure index is component dependent and does not require prior estimation of macro model. Roper and Turnovsky (1980), on the other hand, used an $I S-L M$ framework and derived an optimum trade-off that monetary authorities face between domestic credit and exchange rate changes when stabilising domestic output. Contrary to these studies, Weymark's (1995) Exchange Market Pressure index is model dependent because the weight assigned to its foreign exchange reserve component is derived from an estimated macro model. This converts foreign exchange reserve changes into equivalent exchange rate units and hence ensures that exchange market pressure index is not dominated by more volatile component (Note 1). Since its construction, A Weymark (1995) model has been applied to Australia by Leu (2009), Nicholas and Sofia (2002) to Greece and Akram and Rafique (2013) to Pakistan.

Pakistan adopted managed float exchange rate regime on January 8th, 1982. In July, 2000 the exchange rate policy shifted from a managed float to flexible exchange rate (Khan \& Qayyum, 2008). Besides shift in exchange rate regime, trade and financial liberalization along with lifting of restrictions on capital movement during the decade of 1990s have reduced distortions in the economy. We are of the opinion that shift in exchange rate policy and liberalization of domestic economy may have reduced pressure and hence intervention of Central Bank in foreign exchange market. 
This paper also utilizes Weymark (1995) approach for evaluating the extent of market pressure and Central Bank foreign exchange intervention. Contrary to Frenkel and Aizenman (1982), a Weymark (1995) intervention index describes intervention policies in terms of proportion of exchange market pressure relieved by Central Bank intervention see Nicholas and Sophia (2006). The basic objective is to use exchange market pressure and intervention index values as a tool for analysing monetary policy in Pakistan. This will provide evidence whether the financial liberalization and shift in exchange rate regime has reduced pressure on domestic currency in foreign exchange market. Further, it will help understand whether the monetary authorities target exchange rate stability or prefer domestic objectives when domestic currency is facing pressure in foreign exchange market. The result indicates downward pressure and active Central Bank Intervention. However, post financial liberalization period shows drop in both market pressure and intervention index. This suggests that post financial liberalization period is more tranquil. This also indicates an increase in Central Bank independence in formulating an effective monetary policy.

The rest of the paper proceeds as: in section 2 we derive Exchange Market Pressure and intervention index using Weymark's (1995) approach. Section 3 provides details about the data followed by cointegration analysis in section 4 . The results obtained using vector error correction approach are provided in section 5 and section six concludes.

\section{Methods}

\subsection{The Model}

Weymark (1995) approach is based on money demand, price, interest rate, money supply and monetary authorities' response function and is given as:

$$
\begin{gathered}
m_{t}^{d}=p_{t}+b_{1} y_{t}-b_{2} i_{t}+v_{t} \quad b_{1}>0 \text { and } b_{2}>0 \\
p_{t}=a_{0}+a_{1} p_{t}^{*}+a_{2} e_{t}, a_{1}, a_{2}>0 \\
i_{t}=i_{t}^{*}+E_{t} e_{t+1}-e_{t} \\
m_{t}{ }^{s}=m_{t-1}^{s}+\Delta d_{t}+\Delta f_{t} \\
\Delta f_{t}=-\bar{\rho}_{t} \Delta e_{t}
\end{gathered}
$$

where:

$m_{t}=$ refers to money stock in period $t$;

$P_{t}=$ domestic price level in period $t$;

$y_{t}=$ real domestic income in period $t$;

$i_{t}=$ domestic interest rate level in period $t$;

$v_{t}=$ stochastic money demand disturbance in period $t$;

$e_{t}=$ nominal exchange rate refers to the number of units of domestic currency per unit of foreign currency;

$E_{t} e_{t+1}=$ represents the value that rational agents expect nominal exchange rate will take in period $t+1$ given the information in period $t$.

$\Delta d_{t}=\left[h_{t} D_{t}-h_{t-1} D_{t-1}\right] / M_{t-1}$ where $h_{t}$ is the money multiplier in period $t, D_{t}$ domestic credit and $M_{t-1}$ is the inherited monetary stock in $t$;

$\Delta f_{t}=\left[h_{t} F_{t}-h_{t-1} F_{t-1}\right] / M_{t-1}$ where $F_{t}$ is the stock of foreign exchange reserves in period $t$, with $h_{t}$ and $M_{t-1}$ defined above;

$\bar{\rho}_{t}=$ the policy authority's time-variant response coefficient.

Asterisks denote foreign counterpart of domestic variables. Equation (1) explains that demand for real money balances is positively and negatively associated with real income $\left(y_{t}\right)$ and interest rate $\left(i_{t}\right)$. Equation (2) shows that exchange rate and foreign prices influence domestic prices. However, absolute version of PPP does not necessarily hold. Equation (3) is Uncovered Interest Rate Parity which says that any difference between domestic and foreign interest rate is reflected in expected exchange rate. Equation (4) describes money supply process which depend on inherited money stock $\left(m_{t-1}^{s}\right)$, domestic credit $\left(\Delta d_{t}\right)$ and foreign exchange reserve changes $\left(\Delta f_{t}\right)$. Equation (5) shows that foreign exchange reserve changes due to monetary authorities' response to contemporaneous exchange rate changes. Values of $\bar{\rho}_{t}$ define exchange rate regime of a country. $\bar{\rho}_{t}=0$ implies 
freely float as Central Bank abstains from intervening in foreign exchange market for alleviating market pressure. With $\bar{\rho}_{t}=1$, Central Bank maintains fixed exchange rate system by intervening in foreign exchange market. Values between two extremes indicate intermediate exchange rate system. $\bar{\rho}_{t}<0$ are associated with exchange rate changes that are either of opposite sign or greater than the changes warranted by pure floating system.

Substitution of equation (2) and (3) in equation (1) taking the difference of resulting equation yields:

$$
m_{t}^{d}=a_{0}+a_{1} p_{t}^{*}+\left(a_{2}+b_{2}\right) e_{t}+b_{1} y_{t}-b_{2}\left(i_{t}^{*}+E_{t} e_{t+1}-e_{t}\right)+v_{t}
$$

The continuous money market equilibrium condition $\Delta m_{t}{ }^{s}=\Delta m_{t}{ }^{d}=\Delta m_{t}$ yields:

$$
\begin{aligned}
& -\left(\bar{\rho}_{t}+a_{2}+b_{2}\right) \Delta e_{t}=a_{1} \Delta p_{t}{ }^{*}+b_{1} \Delta y_{t}-b_{2} \Delta i_{t}^{*}-\Delta d_{t}+v_{t}-b_{2} \Delta E_{t} e_{t+1} \text { or } \\
& \Delta e_{t}=\frac{1}{-\left(\bar{\rho}_{t}+a_{2}+b_{2}\right)}\left\lfloor a_{1} \Delta p^{*}+b_{1} \Delta y_{t}-b_{2} \Delta i_{t}^{*}-\Delta d_{t}+v_{t}-b_{2} \Delta E_{t} e_{t+1}\right\rfloor
\end{aligned}
$$

Equation (7) shows that exchange rate changes may occur due to excessive demand for money $\left\lfloor a_{1} \Delta p^{*}+b_{1} \Delta y_{t}-b_{2} \Delta i_{t}^{*}+v_{t}-\Delta d_{t}\right\rfloor$ or because of agents' expectations about future exchange rate changes. $b_{2} E_{t} e_{t+1}>0$ The Central Bank's choice for value of $\bar{\rho}_{t}$ and exchange rate $\left(a_{2}\right)$ and interest rate $\left(b_{2}\right)$ parameters also determine actual exchange rate changes. When $\bar{\rho}_{t}=\infty$, then $\bar{\rho}_{t}+a_{2}+b_{2}=\infty$. This implies $\Delta e_{t}=0$ which is consistent with perfectly fixed exchange rate regime. On the other hand, $\bar{\rho}_{t}=0$ suggest $\Delta f_{t}=0$. This suggests that Central Bank abstains from intervention and let the market forces to determine the value of domestic currency in foreign exchange market. When $-\left[a_{2}+b_{2}\right]<\bar{\rho}_{t}<0, \Delta e_{t}$ are of the same sign but greater that the changes that would have occurred in the absence of Central Bank intervention. Finally, for the values of $\bar{\rho}_{t}<-\left[a_{2}\right.$ $+b_{2}$ ], observed exchange rate changes are of sign opposite to the changes warranted by the absence of Central Bank intervention.

Given $\Delta f_{t}=-\bar{\rho}_{t} \Delta e_{t}$ equation (6) can be written as:

$$
\Delta e_{t}=\frac{-\left\{\left(a_{1} \Delta p_{t}^{*}+b_{1} \Delta y_{t}-b_{2} \Delta i_{t}^{*}+v_{t}-\Delta d_{t}-b_{2} \Delta E_{t} e_{t+1}\right)+\Delta f_{t}\right\}}{a_{2}+b_{2}}
$$

The numerator of equation (8) is the excess demand for domestic currency which is caused by the combination of exogenous disturbance, agents' expectations about exchange rate changes and domestic and foreign macroeconomic variables.

\subsection{Exchange Market Pressure and Intervention Index}

Managed float exchange rate system is characterised by simultaneous changes in exchange rate and foreign exchange reserves. In such a system, calculation of exchange market pressure requires converting foreign exchange reserve changes into equivalent exchange rate units and then combining them with observed exchange rate changes. This assigns low weight to more volatile component and hence ensures equal importance of all components. In case of Central Bank's direct foreign exchange intervention, exchange market pressure can be calculated as:

$$
E M P_{t}=\Delta s_{t}+\eta \Delta f_{t}
$$

Where $\eta$ is a partial derivative of exchange rate with respect to foreign exchange reserve changes and is equal to $\frac{-1}{a_{2}+b_{2}}$. It converts foreign exchange reserve changes into equivalent exchange rate changes and hence ensures that exchange market pressure is not dominated by more volatile component. A negative $\eta$ shows that a fall in foreign exchange reserve is associated with exchange rate deprecation and vice versa.

Based on Exchange Market Pressure index, an intervention index can be constructed as Weymark (1995):

$$
\omega_{t}=\frac{\eta\left(\Delta f_{t}\right)}{E M P_{t}}=\frac{\Delta f_{t}}{\frac{1}{\eta} \Delta s_{t}+\Delta f_{t}}
$$

The intervention index described by equation (10) takes values between $-\infty<\omega_{t}<\infty . \omega_{t}=0$ suggests absence of Central Bank intervention hence pure float exchange rate regime is in operation. $\omega_{t}=1$ shows Central Bank relieves entire pressure through the sale and purchase of foreign exchange reserves. This is consistent with fixed exchange rate regime. $0<\omega_{t}<1$ is consistent with managed float exchange rate regime. $\omega_{t}<0$ shows Central Bank leans with wind-that Central Bank purchases foreign exchange reserves in presence of downward pressure and vice versa. $\omega_{t}>1$ suggests $\left(\Delta f_{t}>E M P_{t}\right)$. Exchange rate moves in the direction 
opposite to that warranted by pressure.

\section{Data}

The data on all variables except nominal Gross Domestic Product and monetary aggregate come from International Monetary Fund International Financial Statistic. Statistical Department State Bank of Pakistan provided us quarterly nominal GDP data. The data on nominal monetary aggregate come from Thomson Reuter's datastream. Real GDP and real monetary aggregate data is obtained by adjusting their nominal counterparts by Pakistan CPI. X-12 ARIMA seasonal adjustment programme was used for seasonally adjusting real GDP and money (M1). Quarterly data from 1976Q1 to 2005Q2 is used. Eviews 6.0 standard version was used for processing the data.

\section{Cointegration Analysis}

Before investigating cointegrating relation, time series properties of the data are examined using Augmented Dicky Fuller (ADF) unit root test. The regression equation features intercept and intercept and trend. Based on Akaike Information Criterion, four lags are used while utilizing ADF test for testing the integrating order of the variables. The estimated ADF test statistics are reported in table 1 for level and first difference of the variables. Table 1 show that the null of unit root cannot be rejected for all variables except foreign price with constant and trend when they appear in level. However, first difference estimates shows that null of nonstationary is rejected in all variables (Note 2). Despite different integrating order (i.e., I(1) and $I(2)$ ), still it is possible for these variables to interact in such a way as to produce an $I(0)$ variable.

Table 1. ADF unit root test

\begin{tabular}{lcccc}
\hline & \multicolumn{2}{c}{ Levels } & \multicolumn{2}{c}{ First Difference } \\
& Constant & Constant and Trend & Constant & Constant and Trend \\
\hline$i_{t}$ & -1.442 & -1.673 & $-10.837^{a}$ & $-10.810^{a}$ \\
$m_{t}$ & -1.750 & -2.950 & $-12.268^{a}$ & $-12.377^{a}$ \\
$P_{t}$ & -0.6071 & -1.010 & $-9.987^{a}$ & $-9.981^{a}$ \\
$P^{*}{ }_{t}$ & -2.853 & $-3.89^{a}$ & $-3.791^{a}$ & $-4.897^{a}$ \\
$e_{t}$ & -0.453 & -2.496 & $-9.386^{a}$ & $-9.531^{a}$ \\
$y_{t}$ & -1.399 & -2.571 & $-10.287^{a}$ & $-10.289^{a}$ \\
\hline
\end{tabular}

Note. a shows significance of variables at $5 \%$ level.

\section{Vector Error Correction Model Results}

Instead of separately estimating real money demand and price equation, a six dimensional vector process is estimated with a view of testing whether there is a evidence of distinct real money demand and price equation relationship in the data. As a priori, we think of two cointegrating vectors governing the long run behaviour of these variables. First cointegrating vector is expressed in terms of real money demand function and is given as:

$$
m_{t}-p_{t}=b_{1} y_{t}-b_{2} i_{t}+v_{t}
$$

where $b_{1}$ and $b_{2}$ denotes income and interest rate elasticity of money demand. It is expected that $b_{1}$ is close to unity, corresponding to a unitary elasticity, and that $b_{2}>0$. Second, if the real exchange rate is stationary, we can expect that:

$$
p_{t}=a_{0}+a_{1} p_{t}^{*}+a_{2} s_{t}
$$

Corresponds to second cointegrating relationship with $a_{1}=a_{2}=1$.

Before estimating six dimensional vector process (i.e., $X_{t}=m_{t}-P_{t}, P_{t}, y_{t}, i_{t}, P^{*}{ }_{t}, s_{t}$ ), residual properties of estimated unrestricted vector Autoregression model are checked. Instead of using some information criterion for determining optimal lag length, we estimated the unrestricted Vector Autoregression model up to eight lags and checked the residuals properties. Table 2 and 3 shows that at the chosen lag length of 6 , residuals all properties except normality are satisfied. 
Table 2. Multivariate residual-based misspecification tests

\begin{tabular}{|c|c|c|c|}
\hline \multirow[t]{2}{*}{ Equation } & \multicolumn{2}{|c|}{ ARCH-LM test } & \multirow[t]{2}{*}{ JB Test } \\
\hline & $\chi^{2}$ & $F_{(A R C H)}$ & \\
\hline$m_{t}$ & $17.4525(0.3569)$ & $1.3331(0.1988)$ & $20.9814(0.000)$ \\
\hline$P_{t}$ & $16.0423(0.45)$ & $1.2083(0.2846)$ & $14.8217(0.0006)$ \\
\hline$i_{t}$ & $5.9074(0.9891)$ & $0.3934(0.9805)$ & $212.4824(0.000)$ \\
\hline$S_{t}$ & $15.1637(0.5124)$ & $1.1258(0.3469)$ & $10.2677(0.0059)$ \\
\hline$P^{*}{ }_{t}$ & $14.5748(0.556)$ & $1.0740(0.3195)$ & $2.8325(0.2426)$ \\
\hline$y_{t}$ & $5.1045(0.9952)$ & $0.3370(0.9913)$ & $95.6015(0.000)$ \\
\hline
\end{tabular}

Table 3. System diagnostics

\begin{tabular}{ccccc}
\hline System Diagnostics & Portmanteau (16 lags) & LM Test & $\chi_{\text {ARCH(Slags) }}^{2}$ & JB Normality Test \\
\hline VAR & 520.0986 & 1.0059 & 2213.7481 & 342.308 \\
& $(0.301)$ & $(0.4832)$ & $(0.4437)$ & $(0.000)$ \\
\hline
\end{tabular}

Table 4 reports the results of cointegration test using the specification that includes real money balances, real domestic income, interest rate, domestic and foreign price indices and Pakistan's nominal exchange rate. The results are based on Pantula (1989) idea which allows us to include an intercept, a trend, a deterministic trend and a quadratic trend in the model. There is conflicting evidence about the presence of long run relationship. However, the number of cointegrating vectors is selected on the basis of maximum eigen value test statistic due to its strong alternative hypothesis compare to trace test statistic (Enders, 2010).

Table 4. Multivariate cointegration results

\begin{tabular}{ccc}
\hline & $\lambda_{\text {trace }}$ rank value & $\Lambda_{\max }$ rank value \\
\hline $\mathrm{r} \leq 5$ & 6.428 & 6.428 \\
$\mathrm{r} \leq 4$ & 15.606 & 9.178 \\
$\mathrm{r} \leq 3$ & $31.279^{a}$ & 15.674 \\
$\mathrm{r} \leq 2$ & 54.393 & $23.144^{a}$ \\
$\mathrm{r} \leq 1$ & 96.549 & 42.155 \\
$\mathrm{r}=0$ & 143.142 & 46.953 \\
\hline
\end{tabular}

Note. $r$ denotes the number of cointegrating vectors. $a$ denotes the rejection of hypothesis at $5 \%$ significant level. The underlying vector auto regression includes only a constant term.

Next exact-identifying (also called non-testable restrictions) and over-identifying (also called testable restrictions) restrictions are imposed. The exact-identifying restrictions identify the cointegrating space and are equal to number of cointegrating vectors (Otero \& Milas, 2001). On the other hand, over-identifying restrictions (also called testable restrictions) are the additional restrictions and are imposed on the cointegrating vectors. The validity of these restrictions is tested using standard likelihood ratio test statistic (Milas, 1999). Given two cointegrating vectors, two non-testable restrictions are imposed on each of the cointegrating vectors. In order to do so the two cointegrating vectors associated with $X_{t}=\left[m_{t}-P_{t}, P_{t}, i_{t}, y_{t}, P^{*}, s_{t}\right]$ are given as:

$$
\Pi_{1}=\left[\phi_{11}, \phi_{12}, \phi_{13}, \phi_{14}, \phi_{15}, \phi_{16}, \phi_{17}\right] \text { and } \Pi_{2}=\left[\phi_{21}, \phi_{22}, \phi_{23}, \phi_{24}, \phi_{25}, \phi_{26}, \phi_{27}\right]
$$

Here $\Pi_{1}$ and $\Pi_{2}$ denote first and second cointegrating vector and denote real money demand $\left(m_{t}-P_{t}\right)$ and price equation $\left(P_{t}\right)$ respectively. Each cointegrating vector contains seven elements, they represent the coefficient of each of the endogenous variable $\left[m_{t}-P_{t}, P_{t}, i_{t}, y_{t}, P_{t}^{*}, s_{t}\right]$ and intercept term, $\mu$ respectively. The non-testable restrictions imposed for identifying cointegrating vectors are given as:

$\phi_{11}=1, \phi_{12}=0$ (real money demand equation) and $\phi_{21}=0, \phi_{22}=1$ (price equation).

The non-testable restrictions imposed on the first cointegrating vector $\phi_{11}$ reveals that it is expressed in terms of real money demand and long run estimate of price equation $P_{t}\left(\phi_{12}=0\right)$ is dropped. The remaining variables 
are included unrestrictly. Similarly the non-testable restrictions imposed on the second cointegrating vectors $\phi_{21}$ allows us to express it in terms of price equation $P_{t}\left(\phi_{22}=1\right)$ and drop long run estimates of real money demand equation $m_{t}-P_{t}\left(\phi_{11}=0\right)$. This also allows us to include the rest of the variables unrestricted in the second cointegrating vector.

The over-identifying restrictions are given as:

$H_{0}^{a}: \phi_{15}=\phi_{16}=0$ (on the real money demand equation);

$\phi_{15}$ and $\phi_{16}$ denote foreign price and exchange rate estimates and are dropped from the first cointegrating vector with a view to normalize it in terms of real money demand equation. Similarly, the testable restrictions imposed on the second cointegrating vector are:

$H_{0}^{b}: \phi_{23}=\phi_{24}=0$ (price equation);

$\phi_{23}$ and $\phi_{24}$ represent interest rate and income estimates and are dropped from the second cointegrating vector with a view of expressing it terms of price equation. The estimated Likelihood Ratio statistic for testing the validity of over-identifying restrictions on the two cointegrating vectors at two degrees of freedom are $10.296[P$ value $=0.801]$ and $3.676[P$ value $=0.999]$ respectively (Note 3$)$. Insignificant estimates of likelihood ratio test statistic distributed as $\chi^{2}$ suggest that that the testable restriction imposed on the two cointegrating vectors cannot be rejected. Hence, we can express two cointegrating vectors in terms of real money demand and price equation as given in Weymark (1995) model and are given as:

$$
\begin{aligned}
m_{t}-p_{t}= & -0.724-0.010 i_{t}+1.191 y_{t} \\
& (-4.788)^{a} \quad(-0.462) \quad(2.561)^{a} \\
p_{t}= & 2.474+1.701 p_{t}^{*}+1.634 s_{t} \\
& (2.035)^{a} \quad(5.632)^{a} \quad(5.305)^{a}
\end{aligned}
$$

Real money demand equation (16) shows insignificant and significant interest rate and real domestic income estimates with negative and positive sign which is in accord with the literature. Similarly, price equation shows significant estimates of both foreign price and exchange rate (Note 4). Further, both exchange rate and foreign price estimates are of positive sign. This confirms purchasing power parity. Exchange market pressure and intervention index mean values for the entire sample period are 0.006 and 0.789 respectively. However, post financial liberalization period shows reduction in market pressure and Central Bank intervention. This suggest that in post financial liberalization, the Central Bank let the market forces to determine the value of domestic currency in foreign exchange market which is consistent with independence of Central Bank in formulating an effective monetary policy.

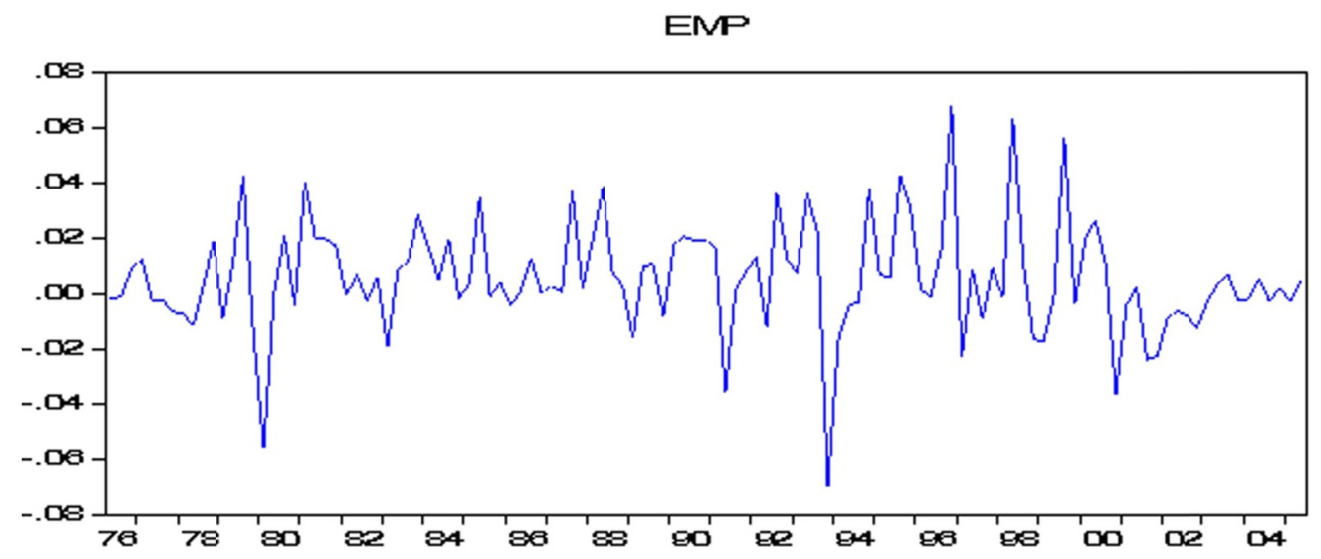

Figure 1. Exchange market pressure

\section{Conclusion}

The paper utilized the approach of Weymark (1995) for constructing exchange market pressure and intervention index for Pakistan. The objective was to provide exchange market pressure and intervention index estimates and 
use the intervention index values as tool for analysing monetary policy in Pakistan over the given sample period. The innovation was to use Johansen (1988) approach to account for data nonstationarity. The results indicate downward pressure and active Central Bank intervention. The intervention index high value for the entire sample period may reflect monetary authorities' fear of potential effect of exchange rate changes on domestic prices and other macroeconomic variables. However, post financial liberalization period shows reduction in both exchange market pressure and the Central Bank foreign exchange intervention which is consistent with increase in Central Bank independence in formulating an effective monetary policy.

This paper utilized general changes in foreign exchange reserves for the construction of exchange market pressure and intervention index for Pakistan. However, this is not a perfect proxy to represent foreign exchange intervention. Mastropasqua et al. (1988) reports that for the period 1983-1985, French Central Bank intervention in foreign exchange market amounted to US $\$ 2.7$ billion. For the same period, there were US $\$ 9.6$ changes in foreign exchange reserves. This shows the extent of difference between general changes in foreign exchange reserves and the changes in foreign exchange reserves that occurs due to Central Bank foreign exchange operation. Given this data limitation, this research can further be improved upon using pure intervention data.

\section{References}

Akram, G. M., \& Ahmad, C. R. (2013). Exchange market pressure and intervention index for Pakistan: Evidence from time varying parameter approach. GSTF International Journal on Business Review, 2, 18-24. http://dx.doi.org/10.5176/2010-48042.4.246

Enders, W. (2010). Applied econometric time series (3rd ed.). John Wiley \& Sons Inc.

Frenkel, J. A., \& Aizenman, J. (1982). Aspects of the optimal exchange rate management. Journal of International Economics, 13, 231-256. http://dx.doi.org/10.1016/0022-1996(82)90056-3

Girton, L., \& Roper, D. (1977). A monetary model of exchange market pressure applied to the post war Canadian experience. The American Economic Review, 67, 537-548.

Khan, M. A., \& Qayyum, A. (2008). Long-run and short-run dynamics of the exchange rate in Pakistan: Evidence from unrestricted purchasing power parity theory. The Lahore Journal of Economics, 13, 29-56.

Leu, S. C. Y. (2009). Managed floating in Australia. Economic Papers, 28, 310-322. http://dx.doi.org/10.1111/j-1759-3441.2010.00039.x

Mastropasqua, C., Micossi, S., \& Rinaldi, R. (1988) Interventions, sterilization and monetary policy in European monetary system countries, 1979-1987. In F. Giavazzi, S. Micossi \& M. Miller (Eds.), The European Monetary System (pp. 252-291). Cambridge, United Kingdom: Cambridge University Press. http://dx.doi.org/10.1017/CBO9780511628535.012

Milas, C. (1999). Long-run structural estimation of labour market equations with an application to Greece. Economic Modelling, 16, 149-161. http://dx.doi.org/10.1016/S0264-9993 (98)00036-4

Nicholas, A., \& Sophia, E. (2002). Measuring exchange market pressure and the degree of exchange market intervention for the Greek Drachma. International Economic Journal, 16, 135-145. http://dx.doi.org/10.1080/10168730200000025

Otero, J., \& Milas, C. (2001). Modelling the spot prices of various coffee types. Economic Modelling, 18, 625641. http://dx.doi.org/10.1016/S0264-9993(00)00056-0

Roper, D. E., \& Turnovsky, S. J. (1980). Optimal exchange market intervention in a simple stochastic macro model. The Canadian Journal of Economics, 13, 296-309. http://dx.doi.org/10.2307/134689

Weymark, D. N. (1995). Estimating exchange market pressure and the degree of exchange market intervention for Canada. Journal of International Economics, 39, 273-295. http://dx.doi.org/10.1016/0022-1996(95)01389-4

\section{Notes}

Note 1. Roper and Turnovsky (1980) and Weymark (1995) require the estimation of six and two parameters respectively from stochastic macro mode for assigning weights to the components of exchange market pressure index.

Note 2. The authors also used Phillips and Perron (PP) unit root test for examining time series properities of the data. The result indicate that null of nonstationarity cannot be rejected in level for all variables. However, all 
variables are stationary at first difference.

Note 3. Degree of freedom is equal to total number of restrictions minus the number of just - identifying restrictions.

Note 4. T-values are obtained by dividing the restricted estimates of parameters of interest with standard errors from unrestricted cointegrating vector.

\section{Copyrights}

Copyright for this article is retained by the author(s), with first publication rights granted to the journal.

This is an open-access article distributed under the terms and conditions of the Creative Commons Attribution license (http://creativecommons.org/licenses/by/3.0/). 